Original Article

\title{
A STUDY ON KNOWLEDGE OF PRIMI MOTHERS ON SELF MANAGEMENT OF MINOR DISCOMFORTS OF PREGNANCY
}

\author{
Sharon Vincent ${ }^{1}$, Sabitha Nayak ${ }^{2} \&$ Shiney Paul ${ }^{3}$ \\ ${ }^{1}$ Post Graduate, ${ }^{2}$ Professor \& Vice Principal, ${ }^{3}$ Professor, Nitte Usha Institute of Nursing Sciences, Nitte University, \\ Paneer, Mangalore, Karnataka, India. \\ Correspondence : \\ Sabitha Nayak \\ Vice Principal, Nitte Usha Institute of Nursing Sciences, Nitte University, Paneer, Mangalore 575 018, Karnataka, India. \\ Mobile : +919448842698 E-mail : sabitha@nitte.edu.in
}

\section{ABSTRACT}

'A study on knowledge of primi mothers on self-management of minor discomfort of pregnancy with a view to develop information' was carried out in Justice K.S Hegde Charitable hospital on 100 primi-gravida mothers by using purposive sampling technique. The findings of the study showed that $87 \%$ of the primi mothers were in the age group of $21-30$ years, $37 \%$ of the women had high school education, $70 \%$ of the subjects were Hindus, $77 \%$ belonged to joint families and $53 \%$ were in the gestational age group of 29-40 weeks.

Most 59\% of the Primigravida mothers had poor knowledge, $29 \%$ had average knowledge, and $12 \%$ had good knowledge regarding minor discomforts of pregnancy and its self-management.

Area wise knowledge of Primigravida mothers reveals deficiency in most of the areas, but the lowest mean percentage of score is $28.25 \%$ with a standard deviation of 1.74 in the area of knowledge related to Circulatory and Nervous system, which indicated that the maximum knowledge deficit is in this area.

There was significant association between knowledge of Primigravida mothers and age, educational qualification. The calculated ${ }^{2}$ values were 3.953 and 12.603 respectively which are more than the table value 3.84 and 7.82 at $0.05 \%$ level of significance. Hence, the research hypothesis was accepted.

The result of the study proved that Primigravida mothers had poor knowledge regarding minor discomforts of pregnancy and its selfmanagement. The findings of the study showed that there was a need to educate all women on preparation towards motherhood. Providing an information booklet on minor discomforts of pregnancy and its management, an uneventful antenatal period can be expected from the mother.

Key words: Minor discomforts of Pregnancy; Primigravida mothers; Knowledge; and Information booklet.

\section{Introduction :}

Pregnancy is a unique and existing time in a woman's life, as it highlights the woman's amazing creative and nurturing powers while providing a bridge to the future. It is not an illness; it is a physiologic and emotional state of being that is associated with hormonal changes and physical changes brought about by an

\begin{tabular}{|c|}
\hline Access this article online \\
\hline Quick Response Code \\
\hline
\end{tabular}
enlarging uterus. ${ }^{1}$ Many women experience some discomfort or minor complaints during pregnancy. Although these discomforts are not dangerous, they can be troublesome. ${ }^{2}$

Professional nurse is an invaluable member of the health care team when working with pregnant patients. Being knowledgeable and capable to support the patient and to give her advice to make her more comfortable is very important during the pregnancy. ${ }^{3}$

The minor discomforts of pregnancy present difficulties for the health care provider as well as for the pregnant woman herself. Management of the various symptoms requires astute observations and the ability to individualize therapy. Knowledge of a variety of treatment options, therefore, allows practitioners to collaborate with their patients in selecting the best therapeutic approach for the specific 
situation. ${ }^{1}$

A survey was conducted to identify factors commonly reported by women that alleviate their symptoms of Nausea and vomiting in pregnancy. All

500 women reported that dietary and lifestyle changes helped to improve their NVP symptoms. This study had identified that NVP is a multifaceted condition.

Lifestyle changes including validation, supportive counseling and dietary adjustments are important components that can be used to counsel women with NVP, concomitantly with safe and effective treatment. ${ }^{4}$

\section{Statement of the Problem :}

"A study on knowledge of Primigravida mothers on selfmanagement of minor discomforts of pregnancy with a view to develop an information booklet in a selected hospital at Mangalore"

\section{Objectives of the Study:}

1. To assess the knowledge of Primigravida mothers regarding minor discomforts of pregnancy and its selfmanagement using a structured questionnaire.

2. To develop an information booklet regarding minor discomforts of pregnancy and its management.

3. To find the association between knowledge score and selected demographic variables.

\section{Review of Literature :}

An exploratory study was conducted in Udupi on discomforts of pregnancy and related practices of antenatal women. The study population comprised of 180 antenatal women. The major findings of the study were majority of antenatal woman $64.4 \%$ suffered from giddiness, nausea \& vomiting.

Nausea and vomiting was higher in terms of percentage of occurrence $40 \%$, giddiness in second trimester $76.6 \%$ and frequency of micturition $100 \%$ in third trimester. Majority of practices related to discomforts were found safe. ${ }^{5}$

A prospective study on epidemiology of nausea and vomiting of pregnancy: prevalence, severity, determinants, and the importance of 12 race/ethnicity were conducted in Canada. Women were asked to fill out a first trimester self-administered questionnaire and were interviewed over the telephone during their 2 nd trimester of pregnancy. Presence of nausea and vomiting of pregnancy was based on the reporting of pregnant women (yes/no); severity of symptoms was measured by the validated modified- PUQE index. Of the 367 women included in the study, $81.2 \%$ were Caucasians, $10.1 \%$ Blacks, $4.6 \%$ Hispanics, and $4.1 \%$ Asians. Multivariate analyses showed that race/ethnicity was significantly associated with a decreased likelihood of reporting nausea and vomiting of pregnancy ${ }^{6}$

A study was conducted in Babol, Northern Iran to determine the effectiveness of ginger in biscuit form for the treatment of Nausea and vomiting during pregnancy on 65 women. The subjects were randomized in a double-blind design and divided into 2 groups to take biscuits. Subjects received 5 ginger biscuits per day or an identical placebo biscuit for 4 days. They graded their severity of nausea using visual analog scale (VAS) and recorded the number of vomiting episodes in the previous 24 hours and again during 4 consecutive days. Five item Likert scales were used to assess the severity of their symptoms. The results revealed that the average VAS scores of day 1-4 of post therapy minus baseline nausea was deceased significantly in ginger (2.6 \pm 1.7$)$ compared with the placebo group (1.4 \pm 1.62) $(P=0.01)$. The numbers of vomiting episodes were 16 also decreased in ginger $(0.96 \pm 0.21)$ and placebo (0.62 \pm . 0.19), the difference being insignificant. A significant difference was seen in intergroup variations per day in both groups. $^{7}$

A review was done to discuss the different types of backache, to provide an overview of diagnosis and treatment options, and to address several controversial issues related to pregnancy-related backaches. The findings stated that gestational backache is a substantial problem and can have a significant impact on a pregnant woman's daily activities. Education is still the first line of 
intervention for preventing backaches related to pregnancy. Non- pharmacological/complementary treatments such as posture adjustment, acupuncture, physical therapy, physiotherapy, yoga, and chiropractic may become the first line of treatment options. ${ }^{8}$

A review article on the management of heartburn in pregnancy reveals that heartburn is a normal consequence of pregnancy. The predominant etiology is a decrease in lower esophageal sphincter pressure caused by hormones, especially progesterone. Serious reflux complications during pregnancy are rare; hence upper endoscopy and

SECTION I: - DESCRIPTION OF SOCIO-DEMOGRAPHIC DATA OF PRIMIGRAVIDA WOMEN

This section represents the frequency and percentage distribution of selected demographic variables of Primigravida woman.

$n=100$

\begin{tabular}{|c|c|c|c|}
\hline SI. No & Sample characteristics & Frequency (f) & Percentage (\%) \\
\hline \multirow[t]{5}{*}{1.} & Age in years & & \\
\hline & $a<20$ & 11 & 11 \\
\hline & b 21-30 & 87 & 87 \\
\hline & c $31-40$ & 02 & 02 \\
\hline & $d>40$ & - & - \\
\hline \multirow[t]{6}{*}{2.} & Education & & \\
\hline & a Graduate and above & 13 & 13 \\
\hline & b PUC & 31 & 31 \\
\hline & c $8-10$ std. & 37 & 37 \\
\hline & d 5-7 std. & 19 & 19 \\
\hline & e $1-4$ std. & - & - \\
\hline \multirow[t]{4}{*}{3.} & Occupation & & \\
\hline & a Professional & 08 & 08 \\
\hline & b Skilled worker & 19 & 19 \\
\hline & c Home maker & 73 & 73 \\
\hline \multirow[t]{5}{*}{4.} & Religion & & \\
\hline & a Hindu & 70 & 70 \\
\hline & b Muslim & 19 & 19 \\
\hline & c Christian & 11 & 11 \\
\hline & d Other & - & - \\
\hline \multirow[t]{5}{*}{5.} & Monthly income & & \\
\hline & a Below 5,000 & 11 & 11 \\
\hline & b $5,001-10,000$ & 59 & 59 \\
\hline & c $10,001-15,000$ & 28 & 28 \\
\hline & d Above 15,000 & 02 & 02 \\
\hline \multirow[t]{3}{*}{6.} & Type of family & & \\
\hline & a Nuclear & 23 & 23 \\
\hline & b Joint & 77 & 77 \\
\hline \multirow[t]{4}{*}{7.} & Gestational Age in week & & \\
\hline & a $0-14$ & 16 & 16 \\
\hline & b $15-28$ & 31 & 31 \\
\hline & c $29-40$ & 53 & 53 \\
\hline
\end{tabular}

other diagnostic tests are infrequently needed. Gastro esophageal reflux disease during pregnancy should be managed with a step-up algorithm beginning with lifestyle modifications and dietary changes. Antacids or sucralfate are considered the first-line drug therapy. If symptoms persist, any of the histamine2-receptor antagonists can be used. Proton pump inhibitors are reserved for women with intractable symptoms or complicated reflux disease. Most drugs are excreted in breast milk. Of systemic agents, only the histamine2-receptor antagonists, with the exception of nizatidine, are safe to use during lactation. ${ }^{9}$

SECTION II : DESCRIPTION OF THE OVERALL KNOWLEDGE OF PRIMIGRAVIDA MOTHERS REGARDING MINOR DISCOMFORTS OF PREGNANCY AND ITS SELF MANAGEMENT

\begin{tabular}{|l|l|c|c|}
\hline SI. No. & Knowledge & Frequency & Percentage \\
\hline 1. & Poor & 59 & 59 \\
\hline 2. & Moderate/average & 29 & 29 \\
\hline 3. & Good & 12 & 12 \\
\hline 4. & Very good/excellent & - & - \\
\hline & Total & 100 & 100 \\
\hline
\end{tabular}

SECTION III: AREA WISE KNOWLEDGE OF PRIMIGRAVIDA WOMEN REGARDING MINOR DISCOMFORTS OF PREGNANCY AND ITS SELF MANAGEMENT

\begin{tabular}{|l|c|c|c|c|}
\hline Areas & $\begin{array}{c}\text { Max. Possible } \\
\text { Score }\end{array}$ & Mean & $\begin{array}{c}\text { Std. } \\
\text { Deviation }\end{array}$ & $\begin{array}{c}\text { Percentage } \\
\text { mean }\end{array}$ \\
\hline $\begin{array}{l}\text { Introduction \& } \\
\text { Digestive system }\end{array}$ & 13 & 5.27 & 2.64 & 40.54 \\
\hline $\begin{array}{l}\text { Musculoskeletal } \\
\text { \& Genitourinary } \\
\text { system }\end{array}$ & 11 & 4.16 & 2.54 & 37.82 \\
\hline $\begin{array}{l}\text { Circulatory \& } \\
\text { Nervous } \\
\text { system }\end{array}$ & 8 & 2.26 & 1.74 & 28.85 \\
\hline $\begin{array}{l}\text { Respiratory, } \\
\text { Integumentary } \\
\text { \& General } \\
\text { discomforts }\end{array}$ & 8 & 4.09 & 1.68 & 51.13 \\
\hline Total score & 40 & 15.79 & 6.99 & 39.475 \\
\hline
\end{tabular}


SECTION IV: ASSOCIATION BETWEEN THE KNOWLEDGE OF PRIMIGRAVIDA MOTHERS REGARDING MINOR DISCOMFORTS OF PREGNANCY AND ITS SELF MANAGEMENT WITH SELECTED SOCIO-DEMOGRAPHIC VARIABLES.

$n=100$

\begin{tabular}{|l|c|c|c|c|c|}
\hline $\begin{array}{l}\text { Variables } \\
\text { Age in years }\end{array}$ & $\begin{array}{c}<\text { median } \\
15\end{array}$ & $\geqslant$ median & $\begin{array}{c}\chi^{2} \text { value } \\
\text { with Yates } \\
\text { correction }\end{array}$ & $d f$ & LOS \\
\cline { 1 - 3 }$<20$ & 9 & 2 & \multirow{2}{*}{3.953} & 1 & $\begin{array}{c}0.047 \\
p<0.05 \\
\mathrm{~S}\end{array}$ \\
\hline Total $\& 31-40$ & 40 & 49 & & & $\mathrm{~s}$ \\
\hline
\end{tabular}

[? 2 (tab) value at $0.05 \mathrm{LOS}$ is $3.84 \mathrm{~S}=$ significant The above table depicts that there is significant association between knowledge of primigravida mothers and age ( $2=3.953, p<0.05$ ) at 0.05 level of significance. Hence research hypothesis is accepted.

\begin{tabular}{|c|c|c|c|c|c|}
\hline \begin{tabular}{|l} 
Variables \\
Educational \\
Qualification
\end{tabular} & $<$ median & $\begin{array}{c}\geqslant \text { median } \\
15\end{array}$ & \begin{tabular}{|c|}
$\chi^{2}$ value \\
with Yates \\
correction \\
\end{tabular} & df & LOS \\
\hline $\begin{array}{l}\text { Graduate or } \\
\text { above }\end{array}$ & 9 & 2 & \multirow{5}{*}{12.603} & \multirow{5}{*}{3} & \multirow{5}{*}{$\begin{array}{c}0.006 \\
p<0.05 \\
s\end{array}$} \\
\hline PUC & 40 & 49 & & & \\
\hline High school & 49 & 51 & & & \\
\hline Middle school & & & & & \\
\hline Total & & & & & \\
\hline
\end{tabular}

[? 2 (tab) value at 0.05 LOS is $7.82 \mathrm{~S}=$ significant The above table depicts that there is significant association between knowledge of Primigravida mothers and educational qualification (? $2=$ $12.603, p<0.05)$ at 0.05 level of significance. Hence research hypothesis is accepted.

\section{Refferences :}

1. Davis CD. The discomforts of pregnancy. JOGN 1996;25:73

2. Healthy Women, Healthy Mothers - An Information Guide - Second Edition. $\mathrm{FCl}, 1995$

3. Hughey M. Obstetric and NewbornCare-1. Edition 200 Texas: Brookside Associates. Available from URL: http://www. brooksidepress.org/Products/Obstetric_and_Newborn_Car_1/lesso n 8 Section 1.htm

4. Chandra K, Magee L, Einarson A, Koren G. Nausea and vomiting in pregnancy: results of a survey that identified interventions used by women to alleviate their symptoms. Available at URL:http://www.informaworld.com/smpp/content $\sim \mathrm{db}=\mathrm{all} \sim$ content= a791322405

5. George R. Discomforts of pregnancy and related practices of antenatal women. Dissertation in MSc Nursing. MAHE Manipal; 2001

6. Lacasse A, Rey E, Ferreira E, Mori C, Bérard A. Epidemiology of nausea and vomiting of pregnancy: prevalence, severity, determinants, and the importance of race/ethnicity. BMC Pregnancy and Childbirth 2009; 9(26). Available from: URL: http://www.biomedcentral.com

7. Basirat Z., Moghadamnia A.A., Kashifard M., Razavi-AS. The effect of ginger biscuit on nausea and vomiting in early pregnancy. Acta Medica Iranica 2009; 47(1): 51-56. Available from: URL: http://pdfcast. org/pdf/

8. Wang, Shu-Ming. Backaches related to pregnancy: the risk factors, etiologies, treatments and controversial issues. Current Opinion in Anesthesiology 2003; 16(3):269-273. Available from: URL: http://journals.Iww.com/co-anesthesiology

9. Richter J. E. Review article: the management of heartburn in pregnancy. Aliment Pharmacol Ther 2005; 22: 749-757.

\section{Methodology:}

The study was descriptive in nature. The main study was conducted in K.S Hegde Charitable Hospital, Mangalore. A total of 100 Primigravida mothers who met the inclusion criteria were selected from antenatal OPD of the hospital by using purposive sampling technique. The instrument used for the study was a self structured questionnaire. The data obtained from the study subjects were analyzed using Descriptive and inferential statistics.

\section{INTERPRETATION AND CONCLUSION}

The result of the study proved that Primigravida mothers had poor knowledge regarding minor discomforts of pregnancy and its self management. The findings of the study showed that there was a need to educate all women on preparation towards motherhood. Providing an information booklet on minor discomforts of pregnancy and its management, and an uneventful antenatal period can be expected from the mother.

Acknowledgements : The authors are thankful to Nitte University for providing necessary facilities to carry out this research work. 